\title{
Trend Detection in Short and Long Duration Storm Events: A Case Study for NSW, Australia
}

\author{
E. Hajani $^{\text {a }}$, A. Rahman a and A. S. Rahman ${ }^{\text {a }}$ \\ ${ }^{a}$ University of Western Sydney, Building XB 2.48, Kingswood, UWS, Penrith NSW 2751, Australia \\ Email: evan.hajani@gmail.com
}

\begin{abstract}
Anthropogenic climate change is one of the key challenges the earth is facing today, which affects many aspects of the environment. Climate change affects hydrological cycle including rainfall, evaporation, soil moisture and catchment runoff. Change in rainfall has significant implications as it influences floods, droughts, vegetation and ecology. There have been numerous studies on trend identification in annual rainfall data; however, a trend in extreme rainfall data has received relatively less attention. Trends in the extreme rainfalls would affect design and operation of many engineering structures in near future. This paper examines the trends in annual maximum rainfall data from 20 pluviograph stations in New South Wales (NSW), Australia by using two non-parametric tests, Mann-Kendall (MK) and Spearman's Rho (SR) tests. Rainfall events data are analysed for fifteen different durations ranging from 6 minutes to 3 days. The relationship between the observed trends and elevations of pluviograph stations, mean annual rainfall and Southern Oscillation Index (SOI) are examined. It is found that trends are generally influenced by these catchment and climate indices; however, no significant link could be established. The results of the MK and SR test statistics are found to be modestly correlated with the mean annual rainfall and the elevation of the pluviograph stations, with a maximum correlation coefficient of 0.31 . It has been found that the correlation coefficient between MK test statistic and mean annual rainfall is higher for the longer durations than the shorter duration rainfall events. In case of correlation between the MK test statistic and elevation, it has been found that the correlation coefficient is higher for the shorter durations than the longer duration events. It has also been found that the SOI index is weakly correlated with monthly maximum rainfall data. Overall, this study shows that there are little trends in the rainfall events data in NSW that could be deemed to be significant.
\end{abstract}

Keywords: Mann-Kendall test, Spearman's Rho test, design rainfall, annual maximum rainfall, Southern Oscillation Index 


\section{INTRODUCTION}

Climate change affects hydrological cycle including rainfall, evaporation, soil moisture and runoff. Trend analysis has extensively been adopted in the past to assess the impacts of climatic change on hydrological time series data. There have been many studies at different parts of the world showing an evidence of statistically significant trends in the historical rainfall and runoff data (e.g. Mansell, 1997; Brunetti et al., 2001; Oguntunde et al., 2006; Budhakooncharoen, 2008; Skaf and Mathbout, 2010; Clarke et al., 2011; Haddad et al., 2011a; Zende et al., 2012; Tang and Arnone, 2013; Ishak et al., 2013; Thomas et al., 2013; AlHouri, 2014; Swain et al., 2015 and Ahmad et al., 2015).

Brunetti et al. (2001) examined trends in seasonal and annual precipitation and number of rainy days data at seven rainfall stations located in northeastern Italy and found a negative trend in the number of wet days. Budhakooncharoen (2008) examined trends in monthly air temperature and precipitation data from 29 stations in Thailand by adopting Mann-Kendall (MK) test and reported an increasing trend in monthly temperature and rainfall data for most of the stations. Landsea et al. (2010) showed that the increasing trend in North Atlantic tropical storm frequency over the past 140 years was principally due to the increasing trend in short duration storms (2 days or less) after the 1940s.

Zende et al. (2012) used the MK test to examine trends in rainfall data at 10 rainfall stations in Western Maharashtra in India and found both increasing and decreasing trends in the monthly rainfall data over large continuous areas. Al-Houri (2014) conducted a trend analysis in daily rainfall data from 15 rain gauges in Amman-Zarqa Basin, Jordan. The analyses showed a decreasing trend in the number of rainy days for most of the stations. Swain et al. (2015) adopted the MK and Sen's slope estimator tests to detect trends in the monthly rainfall data in Raipur district of Chhattisgarh in India and noted a downward trend for most of the cases examined.

In Australia, Hardwick-Jones et al. (2010), Westra and Sisson (2011), Jakob et al. (2011) and Laz et al. (2014) evaluated changes in sub-daily extreme rainfall events in Australia, and found that changes in short duration rainfall events are in greater magnitude than the longer duration events. However, the new design rainfalls in Australia have been derived in 2013 based on a stationary approach i.e. it did not consider the impacts of climate change (e.g. trends in the rainfall data) explicitly on design rainfalls (see Haddad et al., 2015; Haddad and Rahman, 2014, Johnson et al., 2012 and Haddad et al., 2011b). Hence, further research is needed to provide scientific basis on the incorporation of climate change impacts on design rainfalls, which is the motivation behind this study.

The sea level pressure (SLP) between the eastern south Pacific and northern Australia is referred to Southern Oscillation and has been identified as a major driver in climate (Walker and Bliss, 1932). This phenomenon is measured by Southern Oscillation Index (SOI), which is a deviation in the SLPs at Tahiti, in the southcentral tropical Pacific minus that at Darwin on the northern coast of Australia. SOI is generally negative during El Niño and positive during La Niña phases (Berlage, 1966). Different studies have examined the influence of SOI on rainfall indices (e.g. Power et al., 1999; Grimm et al., 2000; Salinger et al., 2001; Folland et al., 2002; Van Oldenborgh et al., 2005 and Ashok et al., 2007). Cane (2005) noted that the weaker El Niño Southern Oscillation (ENSO) cycles of the early and middle Holocene were caused by a reduced amplification of surface water warming in the western equatorial Pacific during the late summer and early fall. Cai and Cowan (2009) explored the similarities and differences between ENSO in terms of their impacts on Australian rainfall and noted that a positive SOI is linked to La Niña phase.

In this study, an attempt has been made to examine the trends in the annual maximum rainfall series data at 20 pluviograph stations in New South Wales (NSW), Australia by using two non-parametric methods, MannKendall (MK) and Spearman's Rho (SR) tests (Mann, 1945; Kendall, 1975; Yue et al., 2002 and Tonkaz et al., 2007) to find if there have been any significant changes in the extreme rainfalls during 1976-2012. Rainfall events data for fifteen different durations ranging from 6 minutes to 3 days were examined for trends. The relationship between the trend statistics and elevations of pluviograph stations, mean annual rainfall and SOI is also examined. 


\section{DATA AND METHODS}

A total of 20 pluviograph stations in NSW, Australia were selected (Figure 1). The pluviograph data length at each of these stations is 37 years covering the period of 1976 to 2012. Annual maximum rainfall events of six sub-hourly durations $(6,12,18$, 24, 30 and 48 minutes), six sub-daily durations (60 minutes, 2, 3, 6, 8 and 12 hours), and three daily durations (24, 48 and 72 hours) were extracted from each of the selected pluviograph stations. The geographical distribution of the selected 20 pluviograph stations is shown in Figure 1, which shows a uniform density of selected stations over the eastern NSW.

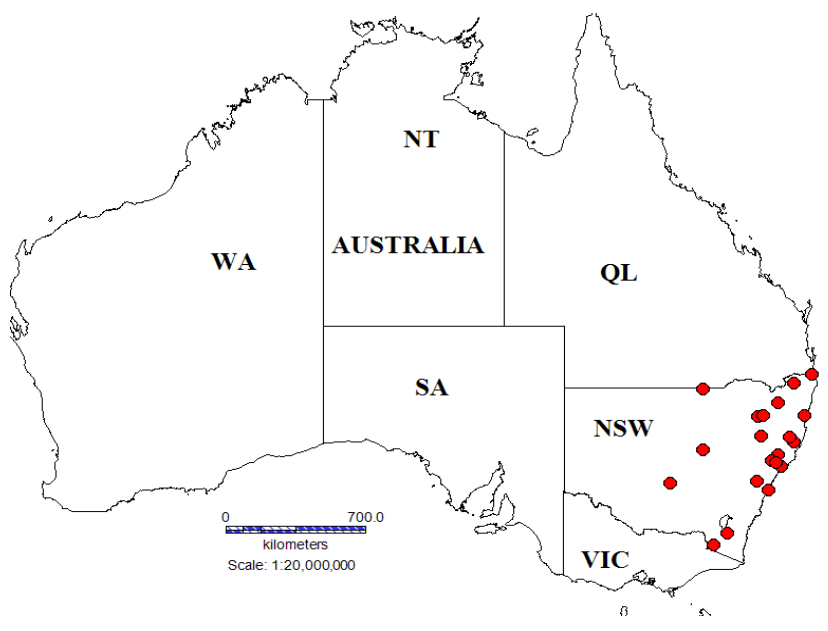

Figure1. Locations of the selected 20 pluviograph stations in NSW, Australia.

Table 1 lists the selected pluviograph stations with record lengths, period of data, latitudes, longitudes, elevation and mean annual rainfalls. The mean annual rainfalls in this region are in the range of $272 \mathrm{~mm}$ (at Naradhan station) to $1481 \mathrm{~mm}$ (at Comboyne station), and the monthly average SOI data covers January 1976 to December 2012 (BOM, 2015). The station elevation ranges $6 \mathrm{~m}$ to $1215 \mathrm{~m}$.

Table 1. Selected pluviograph stations and record lengths.

Two non-parametric approaches (MannKendall (MK) test and Spearman's Rho (SR) test) (see Hajani et al., 2014 for details) were adopted at the $10 \%, 5 \%$ and $1 \%$ significance levels (two-tailed test). By using Microsoft Excel, the correlations between trend statistics and mean annual rainfall and station elevation were investigated. Also, the relationship between monthly maximum rainfall and monthly average SOI at Naradhan and Comboyne stations were examined for 6 minutes rainfall duration.

\section{RESULTS}

Based on the MK and SR tests, the percentage of stations showing positive trends was found to be higher than those showing negative trends especially for the short durations (similar to Hajani et al., 2014). There were little differences between the results by the MK and ST tests. The relationship between the trend statistics and the mean annual rainfall values and the elevations of the stations were examined.

\begin{tabular}{|c|c|c|c|c|c|}
\hline $\begin{array}{c}\text { Station } \\
\text { ID }\end{array}$ & Station Name & $\begin{array}{c}\text { Latitude } \\
(\text { Degree })\end{array}$ & $\begin{array}{c}\text { Longitude } \\
(\text { Degree })\end{array}$ & $\begin{array}{c}\text { Elevation } \\
(\mathrm{m})\end{array}$ & $\begin{array}{c}\text { Mean Annual } \\
\text { Rainfall (mm) }\end{array}$ \\
\hline 051049 & Trangie & -31.9861 & 147.9489 & 215 & 385 \\
\hline 054102 & Barraba & -30.3735 & 150.6723 & 620 & 590 \\
\hline 054105 & Bundarra & -30.3354 & 150.9338 & 880 & 587 \\
\hline 055194 & Gowrie & -31.3365 & 150.8537 & 518 & 580 \\
\hline 056013 & Glen Innes & -29.6953 & 151.6936 & 1060 & 665 \\
\hline 057095 & Tabulam & -28.7551 & 152.4507 & 555 & 898 \\
\hline 058158 & Murwillumbah & -28.3395 & 153.3809 & 8 & 1345 \\
\hline 059026 & Aurania & -30.3076 & 152.9874 & 145 & 1329 \\
\hline 060080 & Comboyne & -31.6274 & 152.4430 & 670 & 1481 \\
\hline 060085 & Yarras & -31.3865 & 152.2482 & 155 & 1308 \\
\hline 061078 & Williamtown & -32.7932 & 151.8359 & 9 & 935 \\
\hline 061151 & Chichester & -32.2426 & 151.6830 & 194 & 1030 \\
\hline 061158 & Glendon & -32.5067 & 151.3779 & 60 & 430 \\
\hline 061250 & Paterson & -32.6296 & 151.5919 & 30 & 737 \\
\hline 063043 & Kurrajong & -33.5347 & 150.6337 & 460 & 762 \\
\hline 066037 & Sydney & -33.9465 & 151.1731 & 6 & 893 \\
\hline 070073 & Chakola & -36.0329 & 149.1323 & 716 & 321 \\
\hline 071042 & Ingebyra & -36.6022 & 148.4677 & 1215 & 575 \\
\hline 075050 & Naradhan & -33.6104 & 146.3161 & 192 & 272 \\
\hline 200288 & Norfolk & -29.0389 & 147.9408 & 111.7 & 1045 \\
\hline
\end{tabular}

Table 2 shows that the correlation coefficients $(r)$ between the trend statistics and mean annual rainfall range between 0.01 and 0.31 . The correlation coefficients between trend test statistics and elevation of the pluviograph stations for the fifteen rainfall durations range 0.02 to 0.21 . 
Hajani et al., Trend detection in short and long duration storm events

Table 2. Correlation coefficients $(r)$ between trend test statistics and Mean Annual Rainfall (MAR) and elevation of pluviograph stations.

\begin{tabular}{|c|c|c|c|c|}
\hline $\begin{array}{c}\text { Rainfall } \\
\text { Duration }\end{array}$ & $\begin{array}{c}r \text { between } \\
\text { MK test } \\
\text { statistic and } \\
\text { MAR }\end{array}$ & $\begin{array}{c}r \text { between } \\
\text { SR test } \\
\text { statistic and } \\
\text { MAR }\end{array}$ & $\begin{array}{c}r \text { between MK } \\
\text { test statistic and } \\
\text { elevation }\end{array}$ & $\begin{array}{c}r \text { between SR } \\
\text { test statistic and } \\
\text { elevation }\end{array}$ \\
\hline 6min & 0.13 & 0.10 & 0.18 & 0.15 \\
\hline $12 \mathrm{~min}$ & 0.30 & 0.20 & 0.12 & 0.12 \\
\hline $18 \mathrm{~min}$ & 0.09 & 0.08 & 0.09 & 0.09 \\
\hline $24 \mathrm{~min}$ & 0.03 & 0.07 & 0.21 & 0.21 \\
\hline $30 \mathrm{~min}$ & 0.03 & 0.05 & 0.20 & 0.19 \\
\hline 48min & 0.01 & 0.03 & 0.18 & 0.18 \\
\hline $60 \mathrm{~min}$ & 0.04 & 0.03 & 0.15 & 0.15 \\
\hline $120 \mathrm{~min}$ & 0.04 & 0.02 & 0.13 & 0.12 \\
\hline $180 \mathrm{~min}$ & 0.02 & 0.02 & 0.06 & 0.06 \\
\hline $360 \mathrm{~min}$ & 0.10 & 0.12 & 0.04 & 0.02 \\
\hline $480 \mathrm{~min}$ & 0.16 & 0.13 & 0.02 & 0.08 \\
\hline $720 \mathrm{~min}$ & 0.09 & 0.13 & 0.08 & 0.06 \\
\hline $1440 \mathrm{~min}$ & 0.31 & 0.25 & 0.06 & 0.07 \\
\hline $2880 \mathrm{~min}$ & 0.24 & 0.16 & 0.08 & 0.17 \\
\hline $4320 \mathrm{~min}$ & 0.16 & 0.16 & 0.18 & \\
\hline
\end{tabular}

Figures 2 to 5 illustrate the relationships between MK test statistics and mean annual rainfall and station elevations for 6 minutes and 1440 minutes rainfall durations. It has been found that the correlation coefficient is higher for longer duration events than the shorter duration ones. In case of correlation between the MK test statistic and elevation, it has been found that the correlation coefficient is higher for the shorter durations than the long duration events.

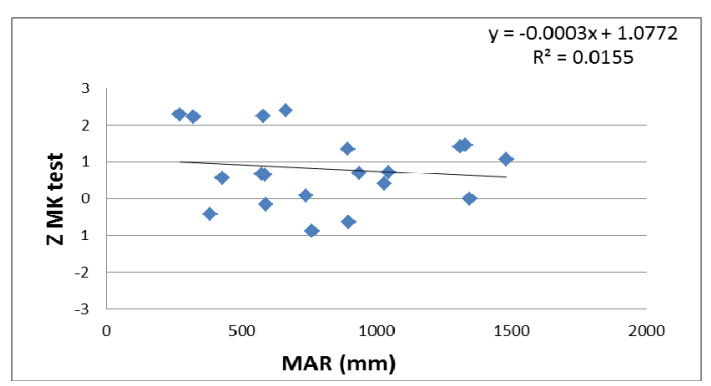

Figure 2. Correlation between MK statistics (Z) and Mean Annual Rainfall (MAR) (6 minutes).

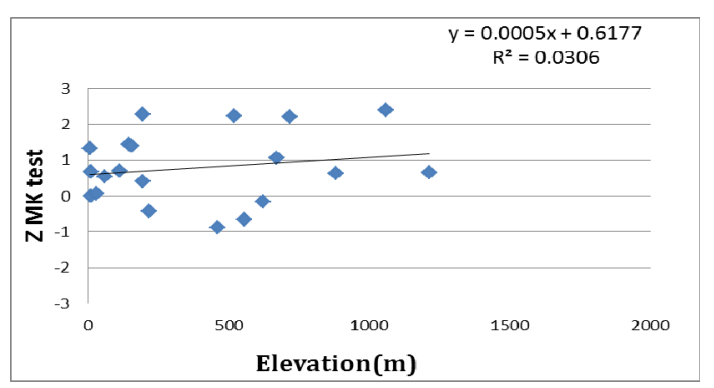

Figure 4. Correlation between MK statistics (Z) and station elevation ( 6 minutes).

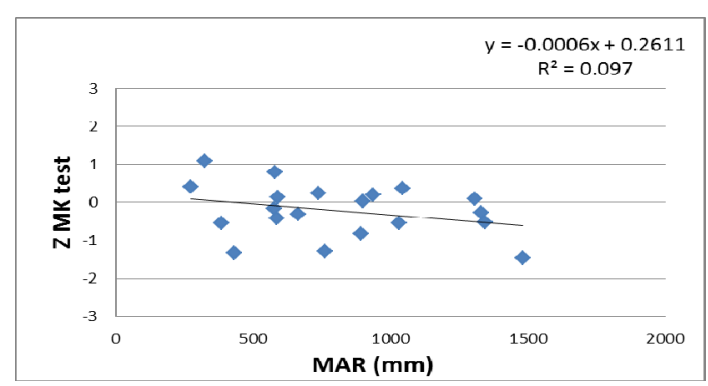

Figure 3. Correlation between MK statistics (Z) and MAR (1440 minutes).

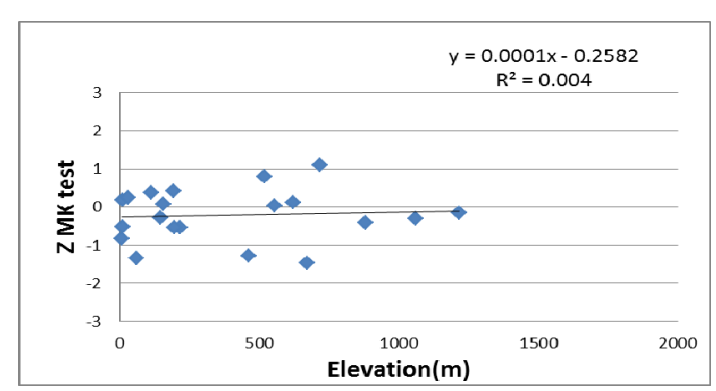

Figure 5. Correlation between MK statistics (Z) and station elevation (1440 minutes). 
Figures 6 and 7 show the monthly maximum rainfall values (represented by green line) for 6 minutes duration against the SOI data (La Nina index is represented by the blue and El Nino by red lines) for Naradhan station (75050) and Comboyne station (60080). The Naradhan station has upward trends at 5\% and $10 \%$ significance levels for the 6 minutes duration monthly maximum rainfall series. The wettest month for Naradhan station (Figure 6) was Feb/1992 (monthly maximum 6 minutes rainfall of $27.3 \mathrm{~mm}$ ), which was associated with warm El Nino phase. The Dec/2000 monthly maximum 6 minutes rainfall of $21 \mathrm{~mm}$ was associated with cold La Nina phase. For Comboyne station (Figure 7), Jan/1978 (monthly maximum 6 minutes rainfall of $27.3 \mathrm{~mm}$ of $10.2 \mathrm{~mm}$ ) was associated with warm El Nino phase and Dec/1996 (monthly maximum 6 minutes rainfall of $11.4 \mathrm{~mm}$ ) was associated with cold La Nina phase. Figures 8 and 9 show that the SOI index is weakly correlated with the monthly maximum rainfall ( $r$ in the range of 0.11 and 0.24 ).

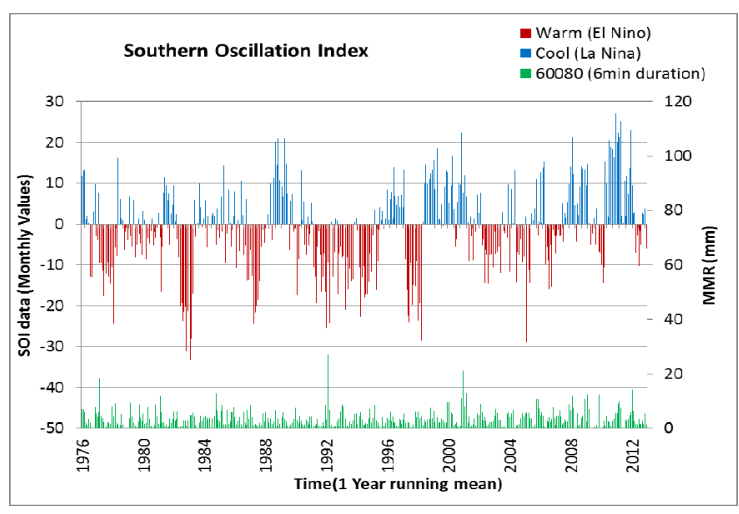

Figure 6. Monthly Maximum Rainfall (MMR) for 6 minues duration vs. monthly SOI during 1976 to 2012 (station 60080).

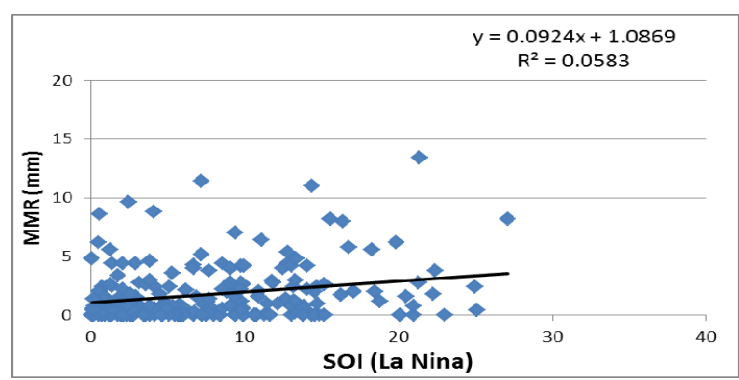

Figure 8. Monthly Maximum Rainfall (MMR) vs. SOI (La Nina) for 6 minutes duration rainfall (station 75050).

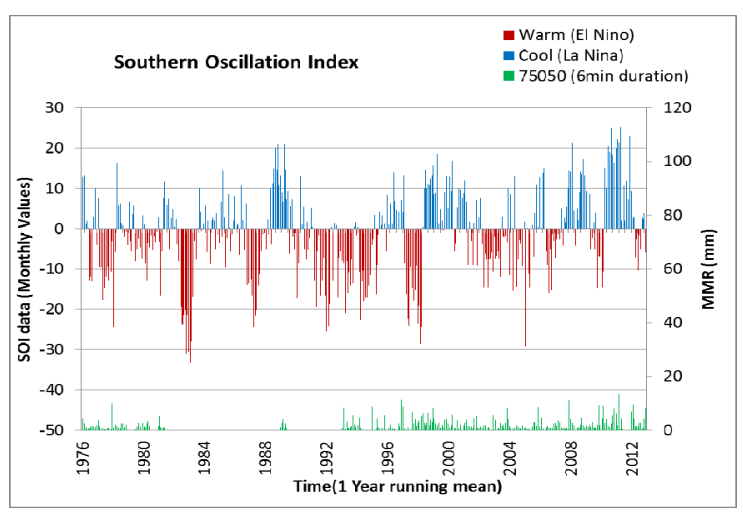

Figure 7. Monthly Maximum Rainfall (MMR) for 6 minutes duration vs. monthly SOI during 1976 to 2012 (station 75050).

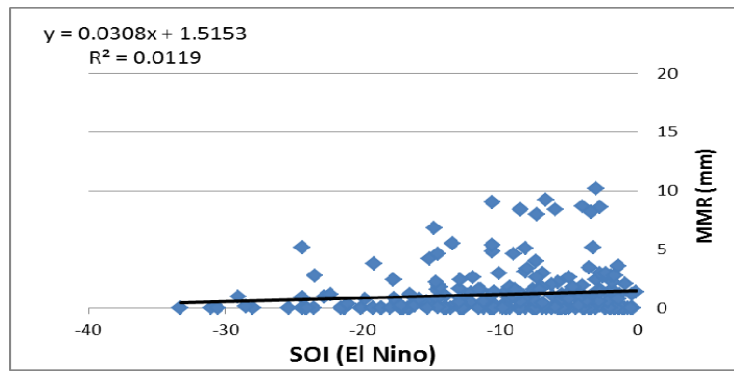

Figure 9. Monthly Maximum Rainfall (MMR) vs. SOI (El Nino) for 6 minutes duration rainfall (station 75050).

\section{CONCLUSIONS}

Two non-parametric tests (Mann-Kendall (MK) test and Spearman's Rho (SR) test) were adopted to examine trends in the annual maximum rainfall events data at 20 pluviograph stations in NSW, Australia. It has been found that the correlation coefficient between the MK test statistic and mean annual rainfall is higher for longer duration than the shorter duration rainfall events. In case of correlation between the MK test statistic and elevation, it has been found that the correlation coefficient is higher for the shorter duration events than the long duration ones. The SOI index is found to be weakly correlated ( $r$ in the range of 0.11 and 0.24 ) with monthly maximum rainfall data. Further study is being conducted as a part of a major project on rainfall estimation under changing climate regime. 
Hajani et al., Trend detection in short and long duration storm events

\section{ACKNOWLEDGMENTS}

We acknowledge the Australian Bureau of Meteorology for proving data for this study and Dr. Elias Ishak and Dr. Khaled Haddad for their input to this study.

\section{REFERENCES}

Australian Bureau of Meteorology, BOM. (2015). S.O.I. (Southern Oscillation Index). http://www.bom.gov.au/climate/current/soihtm1.shtml.

Ahmad, I., Tang, D., Wang, T., Wang, M. and Wagan, B. (2015). Precipitation trends over time using MannKendall and Spearman's rho tests in Swat River Basin, Pakistan. Advances in Meteorology, ID 431860, 115.http://dx.doi.org/10.1155/2015/431860.

Al-Houri, Z. (2014). Detecting variability and trends in daily rainfall characteristics in Amman-Zarqa basin, Jordan. International Journal of Applied Science and Technology, 4(6), 11-23.

Ashok, K., Behera, S.K., Rao, S.A., Weng H. and Yamagata T. (2007). El Nino Modoki and its possible teleconnection. Journal Of Geophysical Research, 112, 1-27, ID:10.1029/2006JC003798.

Berlage, H.P. (1966). The Southern Oscillation and world weather. Mededelingen en verhandelingen 88, Koninklijk Nederlands Meteorologisch Instituut, 152.

Brunetti, M., Maugeri, M., and Nanni, T. (2001). Changes in total precipitation, rainy days and extreme events in northeastern Italy. International Journal of Climatology, 21, 861-871.

Budhakooncharoen, S. (2008). Relation, response and change of near-surface air temperature and rainfall in Thailand. 11th International Conference on Urban Drainage, Edinburgh, Scotland, UK, 1-9.

Cai, W. and Cowan, T. (2009). La Nina Modoki impacts Australia autumn rainfall variability. Geophysical Research Letters, 36, 1-4, ID:10.1029/2009GL037885.

Cane, M.A. (2005). The evolution of El Nino, past and future. Earth and Planetary Science Letters, 230, 227-240, ID:10.1016/j.eps1.2004.12.003.

Clarke, C. Hulley, M., Marsalek, J. and Watt, E. (2011). Stationarity of A max series of short-duration rainfall for long-term Canadian stations: detection of jumps and trends. Canadian Journal of Civil Engineering, 38, 1175-1184.

Folland, C.K., Renwick, J.A., Salinger, M.J. and Mullan, A.B. (2002). Relative influences of the Inter decadal Pacific Oscillation and ENSO on the South Pacific Convergence Zone. Geophysical Research Letters, 29(13), 1-4.

Grimm, A.M., Barros, V.R. and Doyle, M.E. (2000). Climate variability in Southern South America associated with El Nino and La Nina events. Journal of Climate, 13, 35-58.

Haddad, K., Rahman, A., Green, J. and Kuczera, G. (2011a). Design rainfall estimation for short storm durations using L-Moments and Generalised Least Squares Regression-application to Australian data, International Journal of Water Resources and Arid Environments, 1(3), 210-218.

Haddad, K., Rahman, A. and Green, J. (2011b). Design Rainfall Estimation in Australia: A Case Study using L moments and Generalized Least Squares Regression. Stochastic Environmental Research \& Risk Assessment, 25, 6, 815-825.

Haddad, K., Rahman, A. (2014). Derivation of short duration design rainfalls using daily rainfall statistics, Natural Hazards, 74, 1391-1401.

Haddad, K. Johnson, F., Rahman, A., Kuczera, G, Green, J. (2015). Comparing three methods to form regions for design rainfall statistics: two case studies in Australia, Journal of Hydrology, 527 (2015), 6276.

Hajani, E., Rahman, A. and Haddad, K. (2014). Trend analysis for extreme rainfall events in New South Wales, Australia. International Scholarly and Scientific Research and Innovation, 8(12), 704-709.

Hardwick Jones, R., Westra, S. and Sharma, A. (2010). Observed relationships between extreme sub-daily precipitation, surface temperature and relative humidity. Geophysical Research Letters. 37, L22805, 1-5. 
Hajani et al., Trend detection in short and long duration storm events

Ishak, E.H., Rahman, A., Westra, S., Sharma, A. and Kuczera, G. (2013). Evaluating the non-stationarity of Australian annual maximum flood. Journal of Hydrology, 494, 134-145.

Jakob, D., Karoly, D. J. and Seed, A. (2011). Non-stationarity in daily and sub-daily intense rainfall-Part 1: Sydney, Australia. Natural Hazards and Earth System Science, 11(8), 2263-2271.

Johnson, F., Haddad, K., Rahman, A., Green, J. (2012). Application of Bayesian GLSR to estimate sub-daily rainfall parameters for the IFD Revision Project. Hydrology and Water Resources Symposium, 19-22 Nov 2012, Sydney, Australia.

Kendall, M.G. (1975). Rank correlation methods. Griffin Publishers, London, 202.

Landsea, C.W., Bengtsson, L. and Knutson, T. R. (2010). Impact of duration thresholds on Atlantic tropical cyclone counts. Journal of Climate, 23, 2508-2519.

Laz, O. U., Rahman, A., Yilmaz, A. and Haddad, K. (2014). Trends in sub hourly, sub daily and daily extreme rainfall events in eastern Australia. Journal of Water and Climate Change, 5(4), 667-675

Mann, H.B. (1945). Non-Parametric tests against trend. Econometrical, 13, 245-259.

Mansell, M. (1997). The effect of climate change on rainfall trends and flooding risk in the west of Scotland. Nordic Hydrology, 28, 37-50.

Oguntunde, G., Friesen, J., van de Giesen, N. and. Savenije, H.G. (2006). Hydro climatology of the Volta river basin in West Africa: Trends and variability from 1901 to 2002. Physics and Chemistry of the Earth, 31, 1180-1188.

Power, S., Casey, T., Folland, C., Colman, A. and Mehta, V. (1999). Inter-decadal modulation of the impact of ENSO on Australia. Climate Dynamics, 15, 319-324.

Salinger, M.J., Renwick, J.A. and Mullan, A.B. (2001). Inter-decadal Pacific Oscillation and South Pacific Climate. International Journal of Climatology, 21, 1705-1721, ID: 10.1002/joc.691.

Skaf, M. and Mathbout, S. (2010). Drought changes over last five decades in Syria. Options Méditerranéennes, Economics of drought and drought preparedness in a climate change context, 95,107112.

Swain, S., Verma, M. and Verma, M. (2015). Statistical trend analysis of monthly rainfall for Raipur District, Chhattisgarh. International Journal of Advanced Engineering Research and Studies, 87-89.

Tang, G. and Arnone, J.A. (2013). Trends in surface air temperature and temperature extremes in the Great Basin during the 20th century from ground-based observations. Journal of Geophysical Research (Atmospheres), 118: 3579-3589.

Thomas, T., Sudheer, K.P., Ghosh, N.C. and Gunte, S.S. (2013). Spatial-temporal variation of temperature characteristics over Narmada basin is the consistent warming trend a possible climate change signal?. 20th International Congress on Modelling and Simulation, Adelaide, Australia, 2416- 2422.

Tonkaz, T., Çetin, M. and Kâzım, T. (2007). The impact of water resources development projects on water vapor pressure trends in a semi-arid region, Turkey. Climatic Change, 82, 195-209.

Van Oldenborgh, G.J., Philip, S. and Collins, M., 2005. El Nino in a changing climate: a multi-model study Ocean Science Discussions, 2, 267-298, ID:1812-0822/osd/2005-2-267.

Westra, S. and Sisson, S.A. (2011). Detection of non-stationarity in precipitation extremes using a max-stable process model. Journal of Hydrology, 406, 118-128.

Walker, G.T. and Bliss, E.W. (1932). World Weather V. Memoirs of the Royal Meteorological Society, 4, 5384.

Yue, S., Pilon, P. and Cavadias, G. (2002). Power of the Mann-Kendall and Spearman's Rho tests for detecting monotonic trends in hydrological series. Journal of Hydrology, 259, 254-271.

Zende, A.M., Nagarajan, R. and Atal, K. (2012). Rainfall trend in semi-arid region- Yerala river basin of Western Maharashtra, India. International Journal of Advancements in Technology, 3(3), 137-145. 